\title{
Functions of the DRY motif and intracellular loop 2 of human melanocortin 3 receptor
}

\author{
Hui Huang and Ya-Xiong Tao \\ Department of Anatomy, Physiology and Pharmacology, College of Veterinary Medicine, Auburn University, \\ 212 Greene Hall, Auburn, Alabama 36849, USA
}

Correspondence should be addressed to $Y$-X Tao

Email

taoyaxi@auburn.edu

\begin{abstract}
The melanocortin 3 receptor (MC3R) regulates several physiological functions, including feed efficiency, nutrient partitioning, fasting response, natriuresis, and immune reactions. Naturally occurring mutations in the MC3R gene have been shown to be associated with increased adiposity and lung diseases such as tuberculosis and cystic fibrosis. The DRY motif at the cytoplasmic end of transmembrane domain 3 (TM3) and the second intracellular loop 2 (ICL2) are known to be important for receptor function in several G protein-coupled receptors (GPCRs). To gain a better understanding of the functions of this domain in MC3R, we performed alanine-scanning mutagenesis on 18 residues. We showed that alanine mutation of 11 residues reduced the maximal binding and maximal cAMP production stimulated by agonists. Mutation of two residues did not change maximal binding but resulted in impaired signaling in the $\mathrm{G}_{\mathrm{s}}$-CAMP pathway. Mutation of five residues impaired signaling in the ERK $1 / 2$ pathway. We have also shown that alanine mutants of seven residues that were defective in the CAMP pathway were not defective in the ERK1/2 pathway, demonstrating biased signaling. In summary, we demonstrated that the cytoplasmic end of TM3 and the ICL2 were critical for MC3R function. We also reported for the first time biased signaling in MC3R.
\end{abstract}

\section{Key Words}

- melanocortin 3 receptor

- intracellular loop 2

- DRY motif

- MAP kinase

- biased signaling

\section{Introduction}

The melanocortin 3 receptor (MC3R) was identified in 1993 as a receptor for $\alpha$ - and $\gamma$-melanocyte-stimulating hormones (MSHs) (Gantz et al. 1993, Roselli-Rehfuss et al. 1993). It is highly expressed in the hypothalamus, especially in the ventromedial nucleus and arcuate nucleus, as well as in several peripheral tissues, such as the heart, liver, lung, kidney, and macrophages (Gantz et al. 1993, Roselli-Rehfuss et al. 1993, Ni et al. 2003, Getting et al. 2006). Co-expressed with proopiomelanocortin (POMC) in the arcuate nucleus, MC3R acts as an inhibitory autoreceptor, providing a short-loop feedback to regulate POMC neuronal activity (Cowley et al. 2001).

MC3R plays vital roles in regulating various physiological functions. It regulates feed efficiency and nutrient partitioning; $M c 3 r$ knockout mice have elevated fat mass and reduced lean mass (Butler et al. 2000, Chen et al. 2000). More recently, several studies have shown that MC3R is required for normal nutrient anticipatory activities and fasting responses (Sutton et al. 2008, 2010, Renquist et al. 2012). Deletion of $M c 3 r$ results in

Published by Bioscientifica Ltd 
Cushing-like phenotypes with increased basal corticosterone levels and decreased bone density (Renquist et al. 2012). Consistent with an important role of MC3R in regulating energy homeostasis, mutations in $M C 3 R$ have been identified to be associated with human obesity or adiposity (Tao 2010) as well as lung diseases including tuberculosis and cystic fibrosis (Cooke et al. 2008, Wright et al. 2011). In addition to the metabolism-related functions, MC3R is also involved in the regulation of natriuresis (Ni et al. 2003) and immune functions (Getting et al. 2001, 2006).

MC3R is a member of rhodopsin-like family A G protein-coupled receptors (GPCRs). Activation of MC3R results in GDP/GTP exchange in the stimulatory $G$ protein $\left(G_{s}\right)$, which then activates adenylyl cyclase to increase the production of cAMP. Although two studies have reported that MC3R activation stimulates ERK1/2 phosphorylation (Chai et al. 2007, Begriche et al. 2012), an earlier study has reported that while MC4R activation leads to ERK1/2 phosphorylation, MC3R activation does not (Daniels et al. 2003). The existence of biased signaling has been reported in multiple GPCRs with important therapeutic implications (for reviews, see Violin \& Lefkowitz (2007), Rajagopal et al. (2010) and Reiter et al. (2012)). In addition to biased ligands, biased signaling may also be induced by mutations in the GPCRs (Rajagopal et al. 2010). We and others have previously identified both biased ligands and receptors in MC4R (Patten et al. 2007, Büch et al. 2009, Huang \& Tao 2012, Mo et al. 2012, Mo \& Tao 2013; reviewed by Breit et al. (2011) and Tao (2014)). However, until now, no biased signaling of MC3R has been reported. Therefore, it is important to determine whether MC3R mediates ERK1/2 phosphorylation and whether biased signaling also exists in MC3R.

The highly conserved DRYxxI motif at the cytoplasmic end of transmembrane domain 3 (TM3) and the intracellular loop 2 (ICL2) are known to be critical for receptor function in several GPCRs. DRY motif forms salt bridges with surrounding residues and with TM6, which forms an ionic lock constraining the receptor in an inactive conformation (Palczewski et al. 2000, Rosenbaum et al. 2009). Upon ligand binding, the ionic lock is broken and DRY forms new interactions with TM5, stabilizing the receptor in an active conformation (Palczewski et al. 2000, Rosenbaum et al. 2009). ICL2 forms a L-shaped structure or a short $\alpha$-helix parallel to the cell membrane in different GPCRs (Palczewski et al. 2000, Rosenbaum et al. 2009, Chien et al. 2010). ICL2 directly interacts with $G \alpha$ and $\beta$-arrestin and therefore is important for G-protein coupling and receptor desensitization (Han et al. 2001,
Rasmussen et al. 2011). Until now, two residues of MC3R in this region, D178 and I183, have been previously reported to be important for MC3R function (Tao \& Segaloff 2004, Wang et al. 2008). Hence, our knowledge about the function of the DRYxxI motif and ICL2 of MC3R is still very limited. In this study, we investigated the importance of each residue in the DRYxxI motif and ICL2 in regulating receptor cell surface expression, ligand binding, and their different contributions to the two signaling pathways of MC3R.

\section{Materials and methods}

\section{Materials}

$\left[{ }^{125} \mathrm{I}\right]-\left[\mathrm{Nle}^{4}, \mathrm{D}-\mathrm{Phe}^{7}\right]-\alpha-\mathrm{MSH}$ (NDP-MSH) was purchased from the American Radiolabeled Chemicals (St Louis, MO, USA), NDP-MSH from Peptides International (Louisville, KY, USA), and $\alpha$-MSH from Pi Proteomics (Huntsville, AL, USA). Radiolabeled cAMP was iodinated using the chloramine $\mathrm{T}$ method (Tao et al. 2010). The N-terminal $3 \times$ HA tagged WT human MC3R (hMC3R) cloned into pcDNA3.1 was obtained from Missouri S\&T cDNA Resource Center (http://www.cDNA.org/; Rolla, MO, USA).

\section{Site-directed mutagenesis}

Mutant hMC3Rs were generated from the WT receptor using the QuikChange site-directed mutagenesis kit (Stratagene, La Jolla, CA, USA) as described in detail previously (Tao \& Segaloff 2003) using primers listed in Table 1. The presence of desired mutations was verified by direct nucleotide sequencing by the DNA Sequencing Facility of University of Chicago Cancer Research Center (Chicago, IL, USA).

\section{Cell culture and transfection}

Human embryonic kidney 293T (HEK293T) cells and Neuro2a cells were purchased from American Type Culture Collection (Manassas, VA, USA). HEK293T cells were cultured in DMEM supplemented with $10 \%$ newborn calf serum, $10 \mathrm{mM}$ HEPES, 100 units $/ \mathrm{ml}$ penicillin, $100 \mu \mathrm{g} / \mathrm{ml}$ streptomycin, and $0.25 \mu \mathrm{g} / \mathrm{ml}$ amphotericin B. Neuro2a cells were cultured in the same media except that it was supplemented with $10 \%$ fetal bovine serum. Cells were seeded into gelatin-coated six-well clusters and were transfected with $1 \mu \mathrm{g}$ plasmid/well using the calcium phosphate precipitation method for HEK293T cells as described previously (Tao et al. 2010) or using jetPRIME

Published by Bioscientifica Ltd. 
Table 1 Forward primer sequences that were used for site-directed mutagenesis studies. The mutated codons are underlined

\begin{tabular}{l} 
Constructs \\
\hline D178A \\
R179A \\
Y180A \\
V181A \\
T182A \\
I183A \\
F184A \\
Y185A \\
A186G \\
L187A \\
R188A \\
Y189A \\
H190A \\
S191A \\
I192A \\
M193A \\
T194A \\
V195A \\
\hline
\end{tabular}

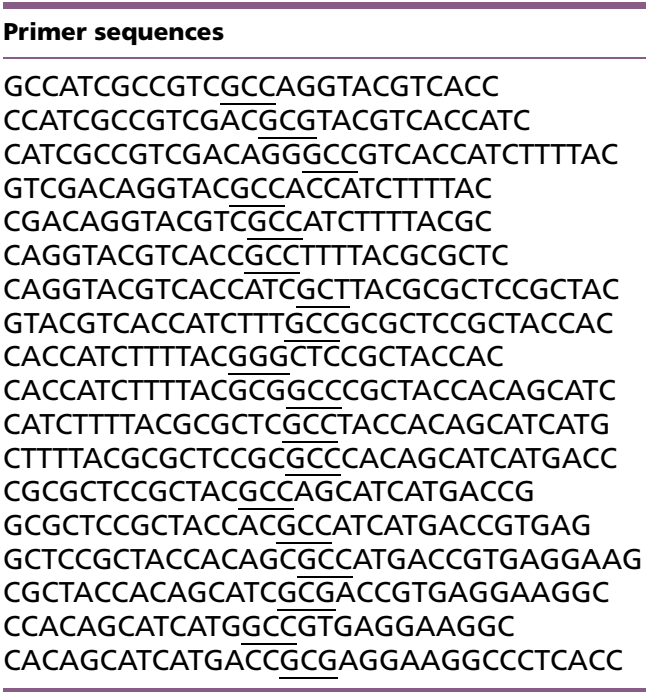

transfection reagent (Polyplus-transfection, New York, NY, USA) for Neuro2a cells (Huang \& Tao 2014, Tao \& Huang 2014). Approximately $48 \mathrm{~h}$ later, cells were used for ligand binding, signaling, or flow cytometry studies. For western blot, HEK293T cells were plated into $100 \mathrm{~mm}$ dishes coated with $0.1 \%$ gelatin and were transfected using the calcium phosphate precipitation method.

\section{Flow cytometry}

HEK293T and Neuro2a cells were seeded and transfected as described above. On the day of experiment, cells in six-well clusters were placed on ice, washed once with ice-cold PBS for immunohistochemistry (PBS-IH; Tao \& Segaloff 2003), detached, and then pelleted by centrifugation at $500 \boldsymbol{g}$ for $5 \mathrm{~min}$. To measure the total expression of receptors, cells were fixed with $4 \%$ paraformaldehyde for $15 \mathrm{~min}$, permeabilized with $0.1 \%$ Triton X-100 in PBS-IH for $15 \mathrm{~min}$, and then blocked with 5\% BSA in PBS-IH for $1 \mathrm{~h}$. To measure the cell surface expression of receptors, cells were directly incubated with the primary antibody after centrifugation. The primary antibody anti-HA.11 (Covance, Princeton, NJ, USA) was added at a dilution of 1:50 in 0.5\% BSA in PBSIH. One hour later, cells were washed once with $0.5 \%$ BSA in PBS-IH and then were incubated with the secondary antibody Alexa Fluor 488-labeled goat anti-mouse IgG (Invitrogen) for $1 \mathrm{~h}$. Cells were washed once with $0.5 \%$ BSA in PBS-IH and assayed using a C6 Accuri Cytometer
(Accuri Cytometers, Ann Arbor, MI, USA). Cells transfected with the empty vector pcDNA3.1 were used for background staining. Calculations were carried out as described previously (Wang et al. 2008).

\section{Ligand binding assay}

HEK293T cells were seeded and transfected as described above. On the day of experiment, cells were washed twice with warm Waymouth's MB752/1 media (Sigma-Aldrich) containing $1 \mathrm{mg} / \mathrm{ml}$ BSA (Waymouth/BSA). Then cells were incubated with 100000 c.p.m. of ${ }^{125} \mathrm{I}-\mathrm{NDP}-\mathrm{MSH}$ and with or without different concentrations of unlabeled $\mathrm{NDP}$ - or $\alpha$-MSH at $37^{\circ} \mathrm{C}$. One hour later, cells were washed twice with ice-cold Hank's balanced salt solution containing $1 \mathrm{mg} / \mathrm{ml}$ BSA to terminate the reaction and then were lysed by $100 \mu \mathrm{l} 0.5 \mathrm{M} \mathrm{NaOH}$. Cell lysates were collected by cotton swabs and counted in a gamma counter. GraphPad Prism (San Diego, CA, USA) was used to calculate receptor occupancy ( $\mathrm{RO}$, as an estimate of maximal binding; Wang et al. 2008) and the concentration that results in 50\% inhibition $\left(\mathrm{IC}_{50}\right)$.

\section{cAMP assay}

HEK293T cells were seeded and transfected as described above. On the day of experiment, cells were washed twice with warm Waymouth/BSA. Then cells were incubated with fresh Waymouth/BSA containing $0.5 \mathrm{mM}$ isobutylmethylxanthine (Sigma-Aldrich) at $37^{\circ} \mathrm{C} 15 \mathrm{~min}$ before the addition of different concentrations of NDP- or $\alpha$-MSH. One hour after incubation with the ligand, cells were lysed with $0.5 \mathrm{M}$ perchloric acid containing $180 \mu \mathrm{g} / \mathrm{ml}$ theophylline (Sigma-Aldrich). The solution was neutralized with $0.72 \mathrm{M} \mathrm{KOH} / 0.6 \mathrm{M} \mathrm{KHCO}_{3}$. Intracellular cAMP levels were measured using RIA as described previously (Tao et al. 2010).

\section{Protein preparation and western blot}

The method for protein preparation and western blot was described previously in detail (Huang \& Tao 2012, Mo et al. 2012). Briefly, HEK293T cells were seeded and transfected as described above. At $24 \mathrm{~h}$ after transfection, cells were starved in Waymouth/BSA for $24 \mathrm{~h}$ at $37^{\circ} \mathrm{C}$. On the day of experiment, cells were stimulated with or without $10^{-6} \mathrm{M}$ $\mathrm{NDP}-\mathrm{MSH}$ for $5 \mathrm{~min}$ at $37^{\circ} \mathrm{C}$. Cells were lysed in $0.5 \%$ NP-40 lysis buffer and total protein concentrations of cell lysates were measured using the Bradford protein assay. Thirty microgram samples were subjected to $10 \%$

Published by Bioscientifica Ltd 
SDS-PAGE and then transferred onto PVDF membranes. Membranes were incubated with $10 \%$ non-fat dry milk containing $0.2 \%$ Tween 20 for at least $3 \mathrm{~h}$ at room temperature, and then immunoblotted with a rabbit phosphorylated ERK1/2 (pERK1/2) antibody (Miyaji et al. 2009) (Cell Signaling, Billerica, MA, USA) at a dilution of 1:1000 and a mouse $\beta$-tubulin antibody (Chu \& Klymkowsky 1989) (Developmental Studies Hybridoma Bank at the University of Iowa, Iowa City, IA, USA) at a dilution of $1: 5000$ in $5 \%$ BSA in Tris-buffered saline containing Tween 20 (TBST) overnight at $4{ }^{\circ} \mathrm{C}$. After three washes in TBST, membranes were incubated with horseradish peroxidase-linked antibodies, an anti-rabbit antibody (Jackson ImmunoResearch, West Grove, PA, USA) at a dilution of 1:2000, and an anti-mouse antibody (Jackson ImmunoResearch) at a dilution of 1:5000 in 10\% non-fat dry milk for $2 \mathrm{~h}$ at room temperature. Antibody binding was detected with ECL reagent (Thermo Scientific, Rockford, IL, USA), and staining intensity was determined using the ImageJ Software (NIH, Bethesda, MD, USA).

\section{Statistical analysis}

All data analyses were performed using the GraphPad Prism 4.0 Software. To compare cell surface expression levels, pERK1/2 levels as well as the binding and signaling parameters between WT and mutant hMC3Rs, Student's $t$-test was carried out.

\section{Results}

\section{Cell surface expression of the mutant hMC3Rs}

To determine the function of each residue at the cytoplasmic end of TM3 and ICL2, we performed alanine-scanning mutagenesis by mutating each residue to alanine or mutating alanine to glycine (Table 1 ). We generated a total of 18 mutants (Fig. 1).

We first quantified the cell surface expression levels of the mutant hMC3Rs. HEK293T cells and Neuro2a cells transiently transfected with the $3 \times$ HA-tagged WT or mutant hMC3Rs were used for flow cytometry studies as described in 'Materials and methods' section. We found that no mutant had decreased cell surface expression levels in HEK293T cells (Fig. 2A). To confirm the results, we further performed flow cytometry studies using Neuro2a cells because MC3R is widely expressed in the CNS. Consistently, no mutant had significantly decreased total expression levels (data not shown) or cell surface expression levels (Fig. 2B) in Neuro2a cells. Compared

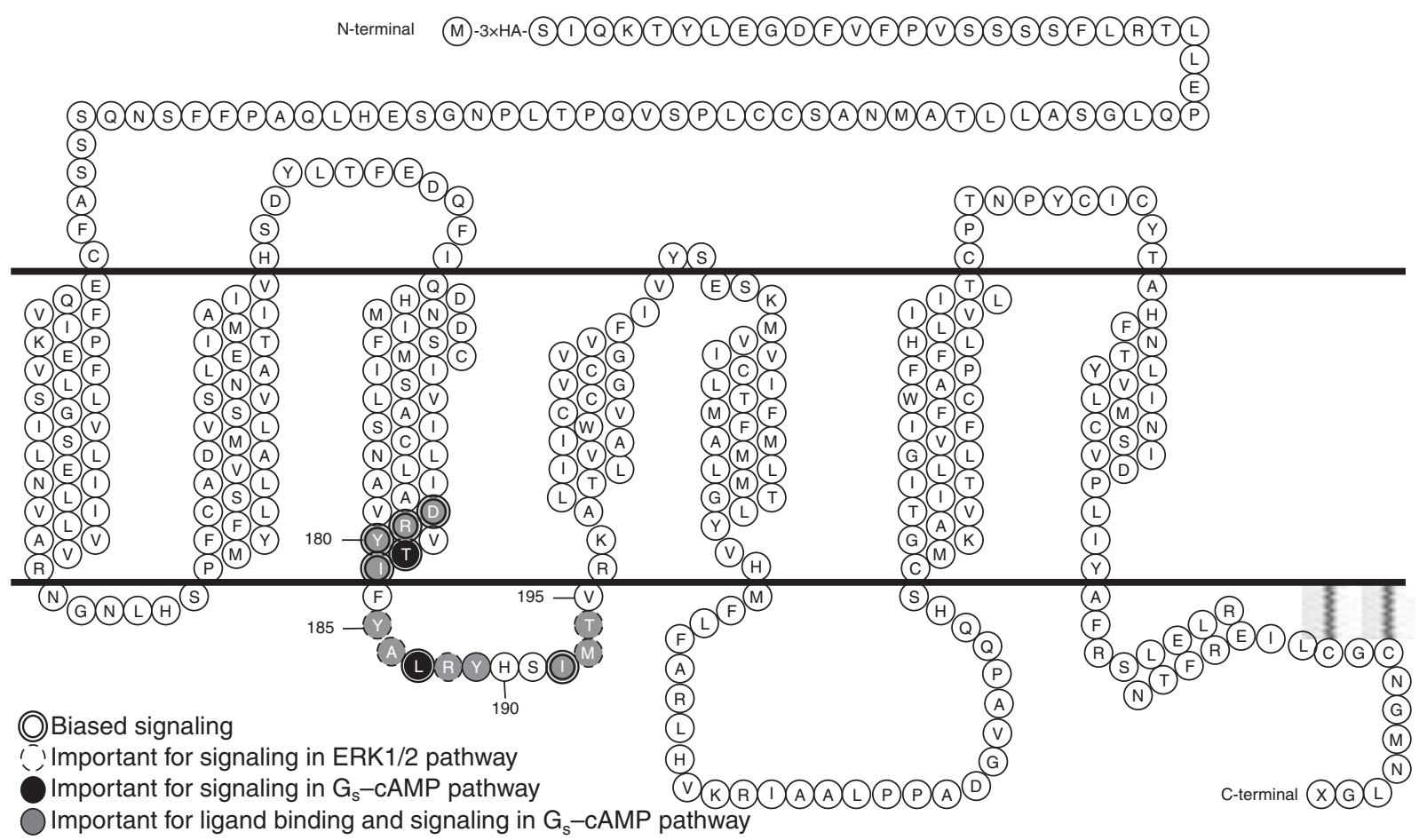

Figure 1

Schematic of hMC3R. Residues that were found to be important for the receptor function are indicated.

http://jme.endocrinology-journals.org DOI: 10.1530/JME-14-0184
() 2014 Society for Endocrinology Printed in Great Britain
Published by Bioscientifica Ltd 

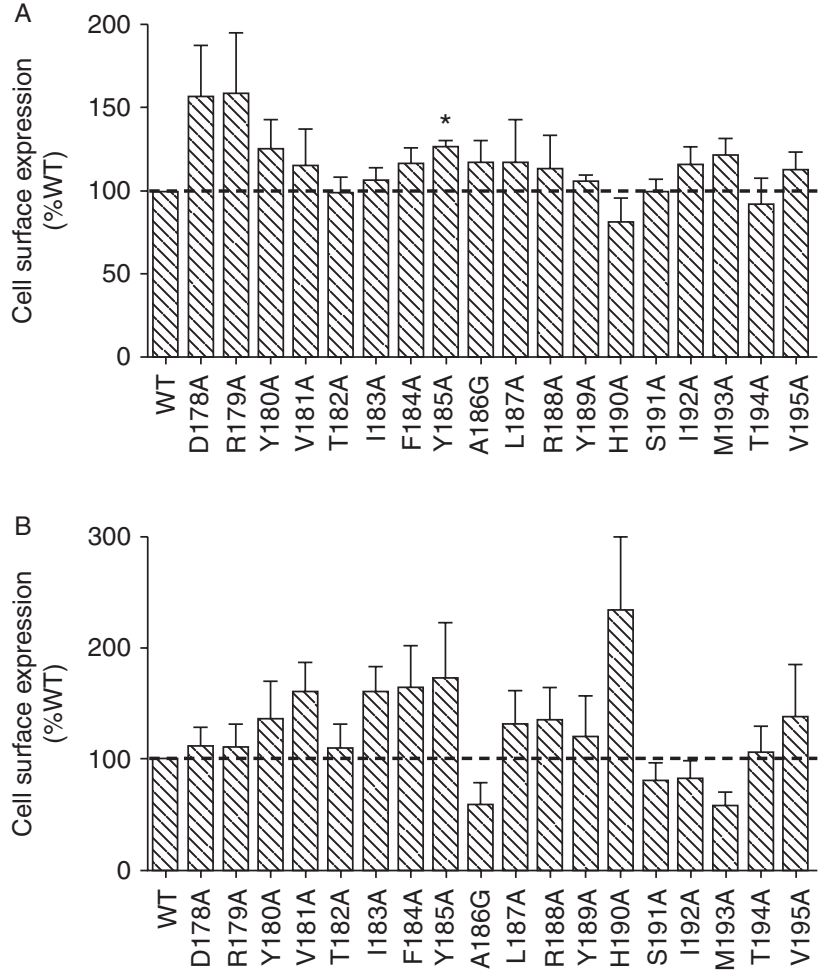

Figure 2

Cell surface expression of the WT and mutant hMC3Rs. HEK293T cells (A) or Neuro2a cells (B) transiently transfected with WT or mutant hMC3Rs were stained with Alexa Fluor 488-conjugated antibody and the immunostaining was measured using flow cytometry. Results are expressed as mean \pm s.E.M. of at least three independent experiments. *Significantly different from the cell surface expression of WT hMC3R, $P<0.05$.

with the WT hMC3R, two mutants (A186G and M193A) had a $40 \%$ reduction in cell surface expression levels that did not reach statistical significance in Neuro2a cells (Fig. 2B).

\section{Ligand-binding properties of the mutant hMC3Rs}

To study ligand binding and signaling properties of the mutant hMC3Rs, two ligands of MC3R, NDP-MSH, and $\alpha$-MSH were used. NDP-MSH is a superpotent agonist and $\alpha-\mathrm{MSH}$ is an endogenous agonist of the melanocortin receptors except for the MC2R. Both ligands are widely used in MC3R studies.

To perform the competitive binding assay, HEK293T cells transiently transfected with the WT or mutant hMC3Rs were incubated with the radiolabeled ${ }^{125}$ I-NDPMSH and different concentrations of unlabeled ligands. NDP-MSH was first studied as the unlabeled ligand. Our data showed that three mutants, D178A, M193A, and T194A, had no detectable binding (Table 2 and Fig. 3). Four mutants, R179A, Y180A, I183A, and I192A, had significantly decreased $\mathrm{IC}_{50} \mathrm{~S}$ compared with the WT hMC3R and therefore increased affinities with the ligand (Table 2 and Fig. 3).

The competitive binding assay was then performed using $\alpha$-MSH as the ligand. Consistently, three mutants, D178A, M193A, and T194A, had no measurable binding, and one mutant $\mathrm{I} 192 \mathrm{~A}$ had decreased $\mathrm{IC}_{50} \mathrm{~s}$ (Table 3 and Fig. 4). By contrast, five mutants, R179A, Y180A, T182A, F184A, and L187A, had increased $\mathrm{IC}_{50} \mathrm{~S}$ (Table 3 and Fig. 4).

RO values were also calculated from the binding assays. In addition to the three mutants with no detectable binding, eight mutants, R179A, Y180A, I183A, Y185A, A186G, R188A, Y189A, and I192A, had significantly decreased RO values compared with the WT hMC3R (Table 2). Two mutants, T182A and L187A, had increased RO by $\sim 50 \%$ (Table 2 ).

\section{Signaling properties of the mutant hMC3Rs in the $\mathrm{G}_{\mathrm{s}}$-CAMP signaling pathway}

To study whether residues in the DRYxxI motif and ICL2 are required for MC3R signaling in the $\mathrm{G}_{\mathrm{s}}-\mathrm{CAMP}$ pathway, HEK293T cells transfected with WT or mutant hMC3Rs were stimulated with different concentrations of the ligand and intracellular cAMP accumulation was measured using RIA. We first studied the signaling properties in response to NDP-MSH. We showed that NDP-MSH increased intracellular cAMP production of WT hMC3R with an $\mathrm{EC}_{50}$ of $0.61 \mathrm{nM}$ in a dose-dependent manner. Four mutants, R179A, I183A, M193A, and T194A, had no response to NDP-MSH stimulation (Table 2 and Fig. 5). Additionally, nine mutants, D178A, Y180A, V181A, T182A, Y185A, A186G, L187A, R188A, and I192A, had significantly decreased maximal cAMP production $\left(R_{\max }\right)$ compared with the WT hMC3R (Table 2 and Fig. 5). Although there was no measurable binding, D178A responded to NDP-MSH stimulation with a reduced $R_{\max }, 13 \%$ of the WT hMC3R. $\mathrm{EC}_{50}$ values of the mutants were also analyzed compared with the WT hMC3R. We showed that two mutants, T182A and L187A, had increased $\mathrm{EC}_{50}$ s (Table 2 and Fig. 5).

The cAMP assay was also carried out using $\alpha$-MSH as the ligand. The $\mathrm{EC}_{50}$ of $\alpha$-MSH was $3.3 \mathrm{nM}$ for the WT hMC3R. Three mutants, I183A, M193A, and T194A, did not respond to $\alpha$-MSH stimulation. Additionally, nine mutants, D178A, R179A, Y180A, Y185A, A186G, L187A, R188A, Y189A, and I192A, had significantly reduced $R_{\max }$

Published by Bioscientifica Ltd. 
Table 2 The ligand binding, basal, and NDP-MSH-stimulated signaling properties of WT and mutant hMC3Rs. Values are expressed as mean \pm S.E.M. of at least three independent experiments for $\mathrm{IC}_{50}, \mathrm{EC}_{50}$, and $R_{\max }$, and at least six independent experiments for RO and basal activities. The $R_{\max }$ of WT hMC3R was $2410.86 \pm 341.73$ pmol/10 $0^{6}$ cells with NDP-MSH stimulation

\begin{tabular}{|c|c|c|c|c|c|c|}
\hline \multirow[b]{2}{*}{ hMC $3 R$ construct } & \multicolumn{2}{|c|}{ NDP-MSH binding } & \multirow[b]{2}{*}{ Basal activities (\% WT) } & \multicolumn{2}{|c|}{ NDP-MSH-stimulated CAMP } & \multirow{2}{*}{$\begin{array}{c}\text { NDP-MSH- } \\
\text { stimulated ERK1/2 }\end{array}$} \\
\hline & $\mathrm{IC}_{50}(\mathrm{nM})$ & RO (\% WT) & & $\mathrm{EC}_{50}(\mathrm{nM})$ & $R_{\max }(\% \mathrm{WT})$ & \\
\hline WT & $3.08 \pm 0.69$ & $100 \pm 0$ & $100 \pm 0$ & $0.61 \pm 0.05$ & $100 \pm 0$ & + \\
\hline D178A & ND & ND & $87.88 \pm 16.26$ & $1.95 \pm 0.67$ & $13.19 \pm 1.28^{\mathrm{a}}$ & + \\
\hline R179A & $0.98 \pm 0.06^{\mathrm{b}}$ & $50.85 \pm 4.69^{a}$ & $91.25 \pm 13.86$ & $\overline{N D}$ & ND & + \\
\hline Y180A & $0.72 \pm 0.16^{c}$ & $13.41 \pm 3.53^{a}$ & $66.23 \pm 11.04^{c}$ & $1.22 \pm 0.34$ & $10.06 \pm 1.95^{\mathrm{a}}$ & + \\
\hline V181A & $1.84 \pm 0.32$ & $103.20 \pm 13.55$ & $144.59 \pm 16.81^{c}$ & $0.49 \pm 0.12$ & $70.46 \pm 10.82^{c}$ & + \\
\hline T182A & $3.07 \pm 0.33$ & $154.30 \pm 21.92^{c}$ & $122.14 \pm 20.05$ & $495.33 \pm 166.65^{c}$ & $61.59 \pm 5.25^{\mathrm{b}}$ & + \\
\hline I183A & $1.16 \pm 0.11^{c}$ & $45.90 \pm 5.95^{\mathrm{a}}$ & $94.7 \pm 17.92$ & ND & ND & + \\
\hline F184A & $2.00 \pm 0.29$ & $91.21 \pm 9.50$ & $79.67 \pm 7.72^{c}$ & $0.46 \pm 0.10$ & $96.43 \pm 10.58$ & - \\
\hline Y185A & $2.62 \pm 0.86$ & $39.16 \pm 5.54^{a}$ & $111.96 \pm 15.87$ & $0.73 \pm 0.22$ & $59.22 \pm 7.18^{c}$ & - \\
\hline A186G & $5.94 \pm 2.25$ & $77.43 \pm 7.58^{c}$ & $86.86 \pm 14.43$ & $1.26 \pm 0.35$ & $42.26 \pm 15.82^{c}$ & - \\
\hline L187A & $3.81 \pm 0.65$ & $152.40 \pm 16.56^{c}$ & $47.51 \pm 10.11^{\mathrm{b}}$ & $3.66 \pm 1.24^{c}$ & $8.65 \pm 2.23^{\mathrm{a}}$ & + \\
\hline R188A & $1.61 \pm 0.26$ & $50.28 \pm 5.07^{a}$ & $74.4 \pm 10.57$ & $0.95 \pm 0.17$ & $39.03 \pm 7.44^{b}$ & - \\
\hline Y189A & $4.69 \pm 1.50$ & $53.34 \pm 8.10^{a}$ & $69.45 \pm 14.37$ & $1.05 \pm 0.23$ & $69.25 \pm 18.45$ & + \\
\hline H190A & $3.34 \pm 1.01$ & $78.47 \pm 13.53$ & $94.97 \pm 18.38$ & $0.47 \pm 0.16$ & $77.13 \pm 19.82$ & + \\
\hline S191A & $2.17 \pm 0.34$ & $97.93 \pm 11.05$ & $84.92 \pm 12.02$ & $0.43 \pm 0.11$ & $91.64 \pm 13.86$ & - \\
\hline I192A & $1.17 \pm 0.31^{c}$ & $24.33 \pm 5.32^{a}$ & $78.43 \pm 16.24$ & $0.49 \pm 0.05$ & $26.30 \pm 7.00^{\mathrm{b}}$ & + \\
\hline M193A & $\bar{N} D$ & ND & $62.87 \pm 16.74$ & $\overline{N D}$ & $\overline{N D}$ & - \\
\hline T194A & ND & ND & $67.25 \pm 17.72$ & ND & ND & - \\
\hline V195A & $4.16 \pm 1.36$ & $88.99 \pm 14.83$ & $98.9 \pm 14.74$ & $0.55 \pm 0.18$ & $99.45 \pm 34.83$ & + \\
\hline
\end{tabular}

ND, not detected; + , activated by $10^{-6} \mathrm{M}$ NDP-MSH; - , not activated by $10^{-6} \mathrm{M}$ NDP-MSH.

a Significantly different from WT hMC3R, $P<0.001$

'significantly different from WT hMC3R, $P<0.01$

'Significantly different from WT hMC3R, $P<0.05$.

(Table 3 and Fig. 6). The results were consistent with the results using NDP-MSH with three exceptions, R179A, Y189A, and S191A. Although they did not respond to NDP-MSH stimulation, R179A partially responded to $\alpha$-MSH stimulation with an $R_{\max } 16 \%$ of the WT hMC3R. Y189A and S191A had similar $R_{\max }$ values with NDP-MSH, but a reduced $R_{\max }$ value with $\alpha$-MSH. When $\mathrm{EC}_{50} \mathrm{~s}$ of the mutants were analyzed, six mutants, D178A, R179A, Y180A, T182A, A186G, and L187A, had a dramatic decrease in $R_{\max }$ (by more than $40 \%$ ) and significantly increased $\mathrm{EC}_{50} \mathrm{~s}$ (Table 3 and Fig. 6).

The basal signaling of MC3R is low compared with another neural melanocortin receptor, the MC4R (Tao 2007, Tao et al. 2010). To study whether the mutants had altered basal signaling, intracellular cAMP concentrations were measured in the absence of any ligand. Our data showed that one mutant, V181A, had significantly increased basal cAMP levels, increased by $\sim 50 \%$ compared with the WT hMC3R. Three mutants, Y180A, F184A, and L187A, had significantly reduced basal cAMP levels (Table 2). The other mutants had similar basal cAMP levels as the WT hMC3R (Table 2).
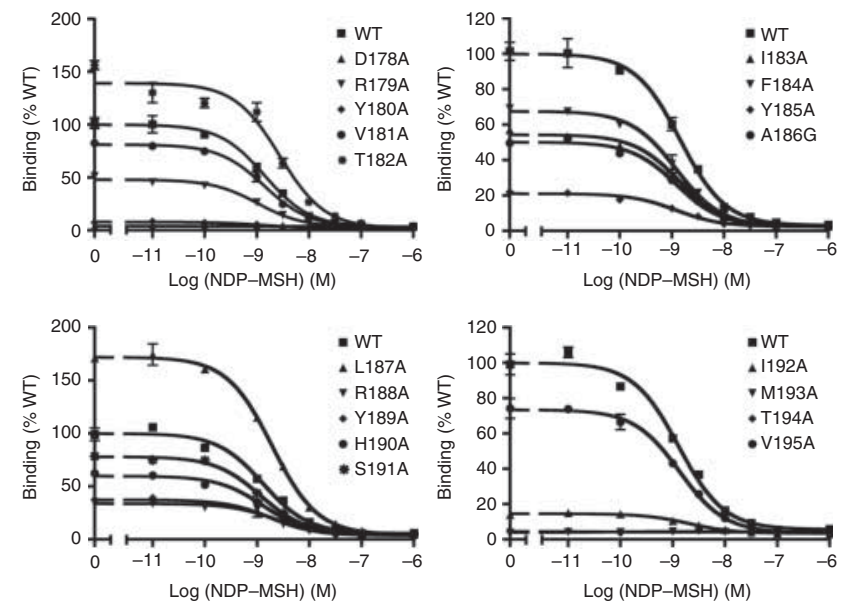

Figure 3

Ligand-binding properties of the WT and mutant hMC3Rs with NDP-MSH as the ligand. Intact cell surface binding was measured by competitive inhibition of ${ }^{125}$ I-NDP-MSH with different concentrations of unlabeled NDP-MSH. Results are expressed as percentage of WT maximal binding. Each point is expressed as mean \pm s.E.M. of duplicate measurements within one experiment. All curves are representative of at least three independent experiments.

Published by Bioscientifica Ltd. 
Table 3 The ligand binding and signaling properties of WT and mutant hMC3Rs in response to $\alpha$-MSH stimulation. Values are expressed as mean \pm s.E.M. of at least three independent experiments. The $R_{\max }$ of WT hMC3R was $2851.50 \pm 466.51$ pmol/10 ${ }^{6}$ cells with $\alpha$-MSH stimulation

\begin{tabular}{lcc}
\hline & & $\alpha-M S H$ binding \\
\cline { 3 - 3 } hMC3R construct & $I_{50}(\mathrm{nM})$ \\
\cline { 1 - 1 } WT & $66.88 \pm 4.57$ \\
D178A & $\mathrm{ND}$ \\
R179A & $280.50 \pm 57.87^{\mathrm{a}}$ \\
Y180A & $84.56 \pm 3.99^{\mathrm{a}}$ \\
V181A & $45.67 \pm 9.66$ \\
T182A & $182.36 \pm 31.63^{\mathrm{a}}$ \\
I183A & $62.42 \pm 9.63$ \\
F184A & $107.99 \pm 7.56^{\mathrm{b}}$ \\
Y185A & $45.46 \pm 8.09$ \\
A186G & $73.55 \pm 6.67$ \\
L187A & $110.61 \pm 13.32^{\mathrm{a}}$ \\
R188A & $46.48 \pm 6.13$ \\
Y189A & $83.14 \pm 13.83$ \\
H190A & $57.31 \pm 2.67$ \\
S191A & $56.82 \pm 3.87$ \\
I192A & $30.89 \pm 2.55^{\mathrm{a}}$ \\
M193A & $\mathrm{ND}$ \\
T194A & $\mathrm{ND}$ \\
V195A & $69.28 \pm 11.74$ \\
\hline
\end{tabular}

\begin{tabular}{|c|c|}
\hline \multicolumn{2}{|c|}{$\alpha$-MSH-stimulated CAMP } \\
\hline $\mathrm{EC}_{50}(\mathrm{nM})$ & $R_{\max }(\% \mathrm{WT})$ \\
\hline $3.30 \pm 1.04$ & $100 \pm 0$ \\
\hline $42.08 \pm 13.49^{b}$ & $9.04 \pm 4.16^{c}$ \\
\hline $63.04 \pm 10.17^{b}$ & $16.07 \pm 2.35^{c}$ \\
\hline $62.38 \pm 9.81^{\mathrm{b}}$ & $10.19 \pm 3.30^{c}$ \\
\hline $2.54 \pm 0.85$ & $89.33 \pm 6.80$ \\
\hline $17.44 \pm 6.39^{b}$ & $62.89 \pm 14.48$ \\
\hline ND & ND \\
\hline $4.37 \pm 2.17$ & $111.96 \pm 16.62$ \\
\hline $7.12 \pm 2.94$ & $44.80 \pm 10.91^{\mathrm{b}}$ \\
\hline $64.98 \pm 17.28^{\mathrm{a}}$ & $36.40 \pm 1.58^{c}$ \\
\hline $65.96 \pm 11.55^{b}$ & $10.79 \pm 1.18^{c}$ \\
\hline $4.43 \pm 0.63$ & $30.67 \pm 7.67^{c}$ \\
\hline $5.47 \pm 0.79$ & $46.41 \pm 7.63^{b}$ \\
\hline $1.28 \pm 0.29$ & $113.66 \pm 15.73$ \\
\hline $1.29 \pm 0.36$ & $82.82 \pm 7.00$ \\
\hline $2.92 \pm 0.49$ & $9.38 \pm 2.39^{c}$ \\
\hline$\overline{N D}$ & ND \\
\hline ND & ND \\
\hline $1.50 \pm 0.48$ & $136.25 \pm 21.23$ \\
\hline
\end{tabular}

ND, not detected.

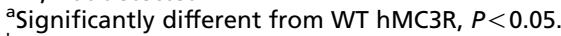

${ }^{\mathrm{b}}$ Significantly different from WT hMC3R, $P<0.01$.

'Significantly different from WT hMC3R, $P<0.001$

\section{Signaling properties of the mutant hMC3Rs in the ERK1/2 signaling pathway}

To study the ERK1/2 signaling pathway of MC3R, HEK293T cells starved for $24 \mathrm{~h}$ were stimulated with or without $10^{-6} \mathrm{M}$ NDP-MSH for $5 \mathrm{~min}$. We showed that stimulation of WT hMC3R with NDP-MSH in turn stimulated ERK1/2 phosphorylation (Fig. 7). Compared with the basal pERK1/2 level, the pERK1/2 level of WT hMC3R was increased by more than twofold in the presence of NDP-MSH. When the 18 mutants were studied, our data indicated that five mutants (Y185A, A186G, R188A, M193A, and T194A) did not respond to NDP-MSH stimulation (Table 2 and Fig. 7). NDP-MSH stimulation increased ERK1/2 phosphorylation in two mutants, F184A and S191A, although not statistically significant, probably due to larger variation and increased basal ERK1/2 activation. The other 11 mutants had significantly increased ERK1/2 phosphorylation when stimulated by NDP-MSH (Table 2 and Fig. 7).

\section{Discussion}

In this study, we systematically studied the function of 18 residues in the DRYXxI motif and the ICL2 of hMC3R.
We showed that i) 11 residues, D178, R179, Y180, I183, Y185, A186, R188, Y189, I192, M193, and T194, were critical for ligand binding and signaling; ii) two residues, T182 and L187, were critical for signaling in the $\mathrm{G}_{\mathrm{s}}-\mathrm{cAMP}$
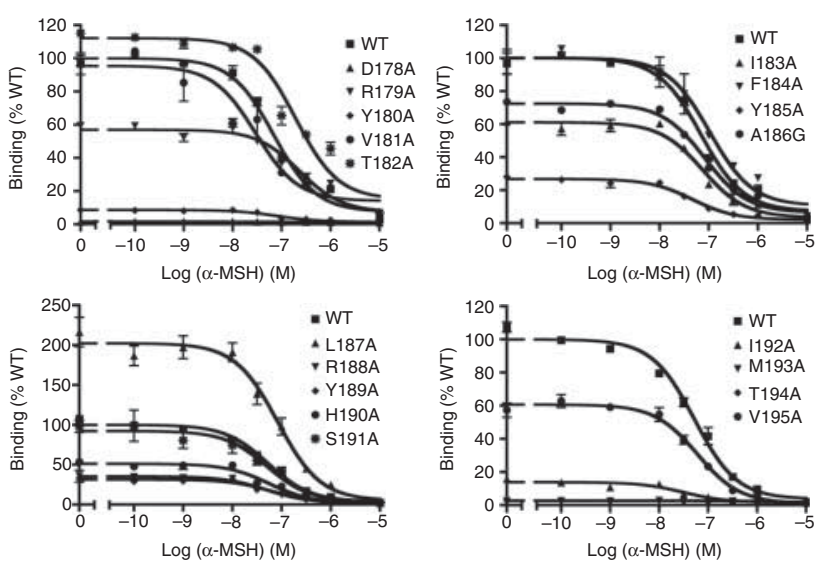

Figure 4

Ligand-binding properties of the WT and mutant hMC3Rs with $\alpha$-MSH as the ligand. Intact cell surface binding was measured by competitive inhibition of ${ }^{125}$-NDP-MSH with different concentrations of unlabeled $\alpha$-MSH. Results are expressed as percentage of WT maximal binding. Each point is expressed as mean \pm s.E.M. of duplicate measurements within one experiment. All curves are representative of at least three independent experiments.

Published by Bioscientifica Ltd. 

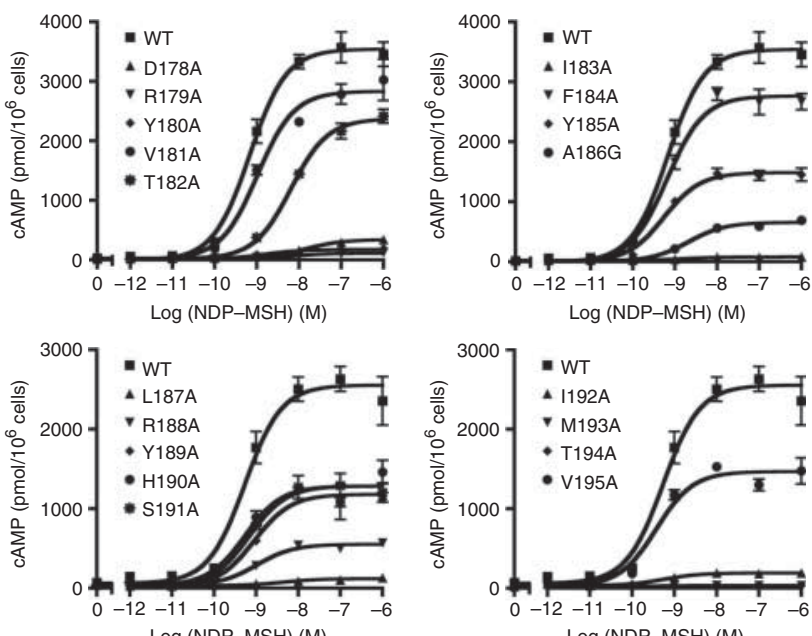

Log (NDP-MSH) (M)

Figure 5

Signaling properties of the WT and mutant hMC3Rs with NDP-MSH as the ligand. HEK293T cells were treated with or without different concentrations of NDP-MSH, and intracellular CAMP accumulations were measured using RIA. Each point is expressed as mean \pm s.E.M. of triplicate measurements within one experiment. All curves are representative of at least three independent experiments.

pathway; iii) five residues, Y185, A186, R188, M193, and T194, were critical for signaling in the ERK1/2 pathway; and iv) seven residues, D178, R179, Y180, T182, I183, L187, and I192, were critical for conferring biased signaling in MC3R.

Alanine or glycine mutations of 11 residues, D178, R179, Y180, I183, Y185, A186, R188, Y189, I192, M193, and T194, did not interfere with the receptor cell surface expression but resulted in decreased RO (Fig. 2, Tables 2 and 3). These mutations might interfere with the ligand binding with a consequent defect in signaling. We have reported previously that $\mathrm{D} 178 \mathrm{E}$ and $\mathrm{D} 178 \mathrm{Q}$ are expressed well on the cell surface but have either no detectable (D178Q) or reduced RO (D178E) (Wang et al. 2008). These 11 residues are located in the cytoplasmic side of MC3R and, therefore, are not expected to directly interact with the ligand. Instead, these residues may indirectly modulate the ligand-receptor interaction through a conformational change. Although it is not a common feature of residues that are important for ligand binding located remotely from the binding sites, observations have been reported previously in MC3R (Wang et al. 2008) as well as other GPCRs, such as gonadotropin-releasing hormone receptor ( $\mathrm{Lu}$ et al. 2005) and V2 vasopressin receptor (Erlenbach et al. 2001).

It has been suggested that $\mathrm{D}^{3.49}$ forms hydrogen bonds with $\mathrm{R}^{3.50}$, which is critical for the conformational switch between inactive and active states of GPCRs (the superscript numbers refer to the Ballesteros \& Weinstein (1995) numbering scheme; Palczewski et al. 2000, Rosenbaum et al. 2007, Wacker et al. 2013). In addition to be involved in multiple intramolecular interactions constraining the receptor in an inactive status (Flanagan 2005), $\mathrm{R}^{3.50}$ has also been indicated to directly contact $\mathrm{G} \alpha$ stabilizing the active status of the receptor-G protein complex upon ligand binding (Scheerer et al. 2008,

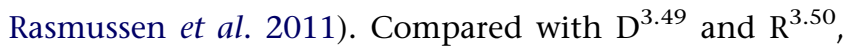
$\mathrm{Y}^{3.51}$ is the least conserved in the DRY motif. The side chain of $\mathrm{Y}^{3.51}$ has been indicated to direct toward the inside of the receptor and form hydrophobic interaction with $\mathrm{P}^{3.57}$ in rhodopsin (Okada et al. 2001). Consistent with these well-known findings, we observed that the DRY motif of MC3R also played a vital role in MC3R binding and signaling (Fig. 2, Tables 2 and 3).

Alanine mutant of $\mathrm{I}_{183^{3.54}}\left(\mathrm{I} 183^{3.54} \mathrm{~A}\right)$ with partially reduced RO did not respond to NDP- or $\alpha$-MSH stimulation (Tables 2 and 3). We reported that mutations of I183 ${ }^{3.54}$ to polar residues result in a profound loss of function, whereas valine mutation $\left(\mathrm{I} 183^{3.54} \mathrm{~V}\right)$ does not alter receptor activity (Tao \& Segaloff 2004), implying that I183 $3^{3.54}$ forms hydrophobic interactions required for MC3R activation. Phosphorylation of $\mathrm{T} 157^{3.65}$ has been suggested to regulate the forward trafficking of MC1R (Sanchez-Laorden et al. 2009). However, in MC3R,
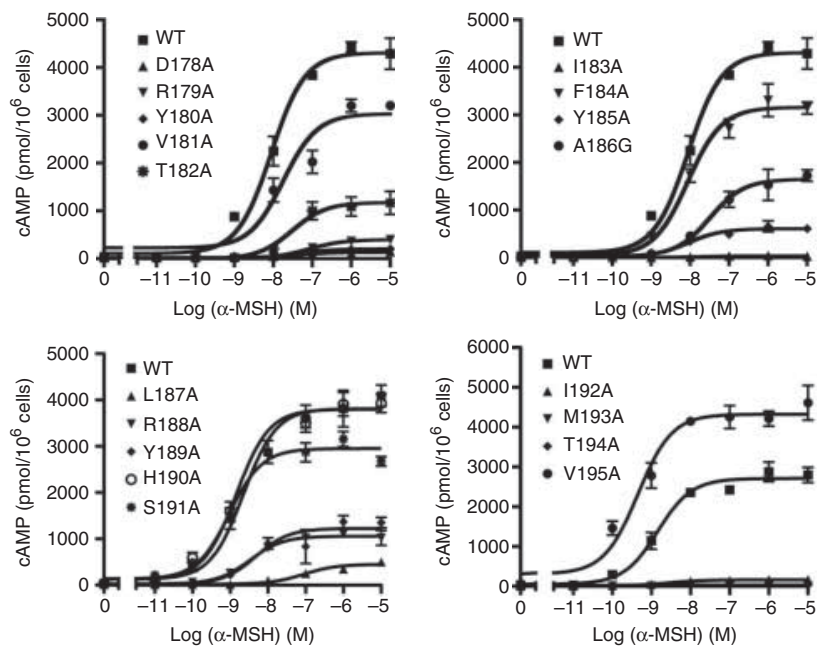

Figure 6

Signaling properties of the WT and mutant hMC3Rs with $\alpha$-MSH as the ligand. HEK293T cells were treated with or without different concentrations of $\alpha-\mathrm{MSH}$, and intracellular cAMP accumulations were measured using RIA. Each point is expressed as mean \pm s.E.M. of triplicate measurements within one experiment. All curves are representative of at least three independent experiments. 

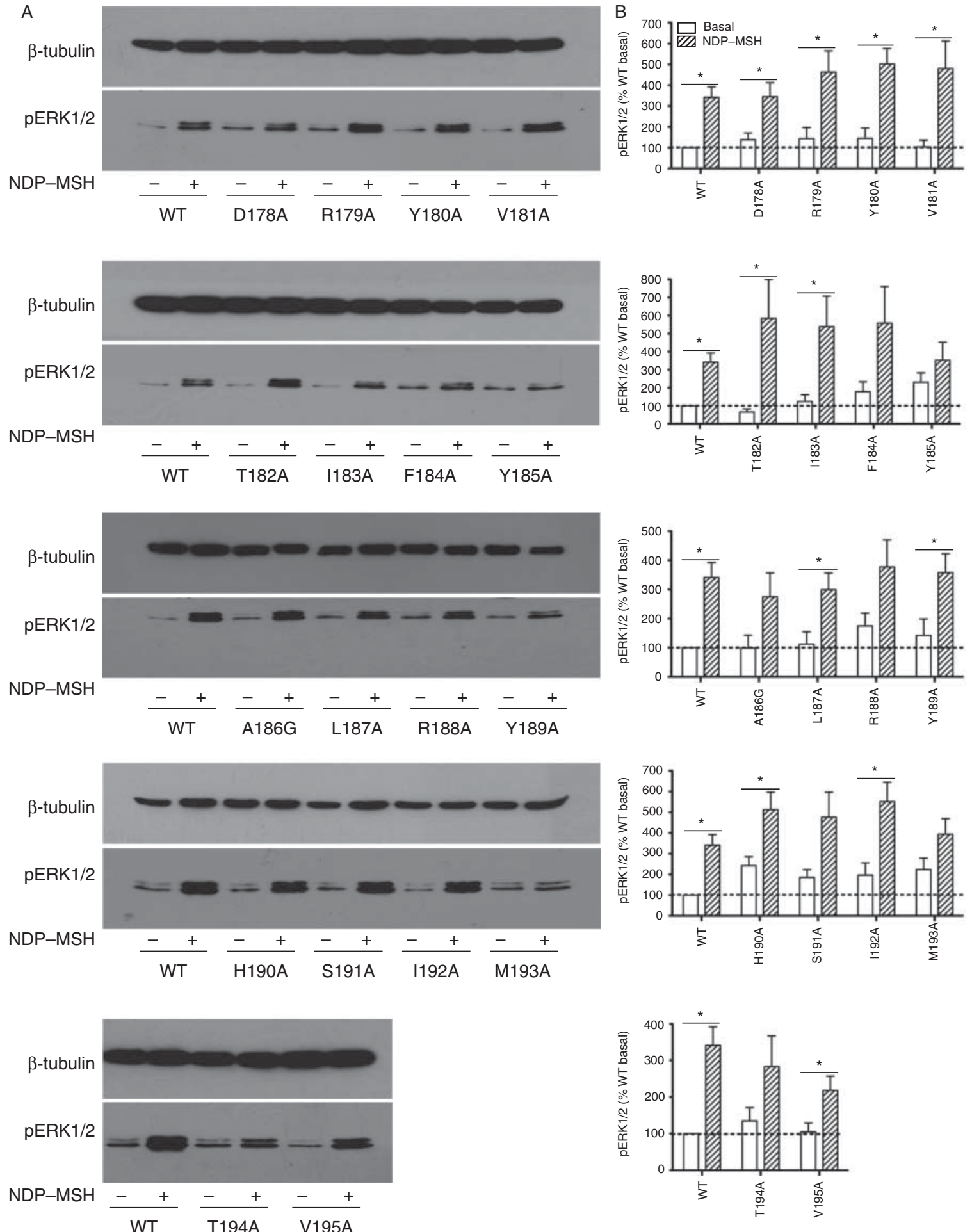

\section{Figure 7}

ERK1/2 signaling properties of the WT and mutant hMC3Rs. In (A), HEK293T cells were transiently transfected with WT or mutant hMC3Rs. Cells were starved for $24 \mathrm{~h}$ and then stimulated with or without $10^{-6} \mathrm{M}$ NDP-MSH for $5 \mathrm{~min}$. Lysates were analyzed by western blot using antibodies against pERK $1 / 2$ or antibodies against $\beta$-tubulin as a control. In (B), results are expressed as mean \pm S.E.M. of at least four independent experiments. *Significantly different from the basal signaling of WT or mutant hMC3Rs, $P<0.05$. Images had not been modified and are representative of at least four independent experiments. The $\beta$-tubulin and pERK $1 / 2$ bands were developed from the same blot.

Published by Bioscientifica Ltd 
T194 $4^{3.65}$ did not affect MC3R trafficking but abolished MC3R binding and signaling.

Although $\mathrm{T} 182^{3.53} \mathrm{~A}$ and $\mathrm{L} 187^{3.58} \mathrm{~A}$ bound similarly with the ligands as the WT hMC3R, they had impaired cAMP production upon NDP- or $\alpha$-MSH stimulation (Tables 2 and 3). These two positions are highly conserved in rhodopsin-like GPCRs, with $79 \%$ being $\mathrm{A} / \mathrm{S} / \mathrm{T}$ at position 3.53 and $75 \% \mathrm{I} / \mathrm{L} / \mathrm{V} / \mathrm{F}$ at position 3.58 respectively (Marion et al. 2006). The position 3.58 was reported to be critical for $G$ protein coupling, and mutations result in impaired receptor activation in $\beta_{2}$ - $\mathrm{AR}\left(\mathrm{F} 139^{3.58} \mathrm{~A}\right.$; Rasmussen et al. 2011) and GPR54 (L148 ${ }^{3.58}$ S; Wacker et al. 2008). Consistently, our data indicated that L187 $7^{3.58}$ was also a key residue in MC3R activation.

The basal activity of MC3R is relatively low compared with the closely related MC4R. Until now, there is only one artificial mutation of MC3R, $\mathrm{F} 347^{7.64} \mathrm{~A}$, that has been reported to be constitutively active (Tao et al. 2010). In this study, we found that only one mutant $\left(\mathrm{T} 182^{3.53} \mathrm{~A}\right)$ had a less than twofold increase in basal activity. It has been suggested that the hydrogen bonding interaction between $\mathrm{D}^{3.49}$ and $\mathrm{Y}^{3.60}$ in $\beta_{1}$-AR and $\mathrm{A}_{2 \mathrm{~A}}$-adenosine receptor accounts for their low basal activities, whereas the interaction between $\mathrm{D}^{3.49}$ and $\mathrm{S}^{3.62}$ in $\beta_{2}$-AR accounts for its high basal activity (Jaakola et al. 2008, Rosenbaum et al. 2009). In the $M C 4 R$, mutation of $D 146^{3.49} \mathrm{~N}$ identified from obese patients pronouncedly increases the basal activity (Wang \& Tao 2011). However, in this study, alanine mutation of $\mathrm{D} 178^{3.49} \mathrm{~A}$ and $\mathrm{Y} 189^{3.60} \mathrm{~A}$ had no effect on the basal activity of MC3R, implying that such hydrogen bonding interactions do not exist or do not affect the basal activity of MC3R. There is usually a correlation between the basal activity of the WT receptor and the propensity of mutations to be constitutively active (Tao et al. 2002, Tao 2008). As MC3R basal activity is low, the propensity of MC3R mutations to be constitutively active is probably low.

To delineate the ERK1/2 signaling pathway of MC3R, we also studied the pERK1/2 levels of WT and mutant hMC3Rs stimulated with NDP-MSH. We showed that activation of MC3R by NDP-MSH activated ERK1/2. Five mutants, Y185A, A186G, R188A, M193A, and T194A, did not activate ERK1/2 when stimulated with NDP-MSH; these mutants also had decreased maximal cAMP production. Interestingly, some of the mutants with decreased RO, especially D178A that had almost no detectable binding, still functioned well in ERK1/2 signaling. It is possible that the mutation D178A increased the disassociation rate of the ligand from MC3R, resulting in decreased RO; however, as ERK1/2 activation is rapid and transient, ERK1/2 was still activated. ERK1/2 are known to be involved in various processes, such as cell proliferation and cell migration (Roskoski 2012). However, the physiological role of ERK1/2 mediated by MC3R is still not clear. Further studies need to be conducted to determine and differentiate the different functions of the cAMP and ERK1/2 pathways of MC3R.

Seven mutants (D178A, R179A, Y180A, T182A, I183A, L187A, and I192A) that had very low or even no cAMP production had similar ERK1/2 signaling as the WT MC3R, suggesting that these seven mutants had ERK1/2 biased signaling (Table 2 and Fig. 7). A previous study had reported that MC3R induces ERK1/2 phosphorylation not through cAMP-PKA but through phospho-inositol-3 kinase (Chai et al. 2007). To the best of our knowledge, this is the first report describing biased signaling in MC3R. Biased signaling induced either by mutation or by biased ligand has been reported in the MC4R (Patten et al. 2007, Büch et al. 2009, Huang \& Tao 2012, Mo et al. 2012, Mo \& Tao 2013; reviewed by Breit et al. (2011) and Tao (2014)) and several other GPCRs (reviewed by Violin \& Lefkowitz (2007) and Lefkowitz (2013)). It has been suggested that biased ligands interact with different residues of the receptor and, therefore, induce different conformational changes in $\beta_{1}$-AR (Warne et al. 2012) and serotonin receptors (Wacker et al. 2013). The biased mutants of MC3R might also have different structures from the WT receptor and, consequently, have different signaling capacities when stimulated by NDP-MSH.

In summary, our present data demonstrated that the cytoplasmic end of TM3 and ICL2 were critical for MC3R function. We identified residues that were critical for ligand binding, signaling in the $\mathrm{G}_{\mathrm{s}}-\mathrm{cAMP}$ pathway, and signaling in the ERK1/2 pathway. We also reported biased signaling of MC3R that advances our understanding of the complexity of the MC3R signaling cascades and also might have therapeutic potential.

\section{Declaration of interest}

The authors declare that there is no conflict of interest that could be perceived as prejudicing the impartiality of the research reported.

\section{Funding}

This study was supported by grants from the National Institutes of Health R15DK077213 and Animal Health and Disease Research Program of Auburn University College of Veterinary Medicine.

\section{Acknowledgements}

The authors thank Dr Shu-Xiu Wang for generating the mutant constructs and performing some of the preliminary experiments. The E7 $\beta$-tubulin

Published by Bioscientifica Ltd. 
antibody developed by M Klymkowsky was obtained from the Developmental Studies Hybridoma Bank developed under the auspices of the NICHD and maintained by the University of lowa, Department of Biology, lowa City, IA 52242, USA.

\section{References}

Ballesteros JA \& Weinstein H 1995 Integrated methods for the construction of three-dimensional models and computational probing of structure-function relations in G protein-coupled receptors. Methods in Neuroscience 25 366-428. (doi:10.1016/S1043-9471(05)80049-7)

Begriche K, Marston OJ, Rossi J, Burke LK, McDonald P, Heisler LK \& Butler AA 2012 Melanocortin-3 receptors are involved in adaptation to restricted feeding. Genes, Brain, and Behavior 11 291-302. (doi:10.1111/j.1601-183X.2012.00766.x)

Breit A, Büch TR, Boekhoff I, Solinski HJ, Damm E \& Gudermann T 2011 Alternative $\mathrm{G}$ protein coupling and biased agonism: new insights into melanocortin-4 receptor signalling. Molecular and Cellular Endocrinology 331 232-240. (doi:10.1016/j.mce.2010.07.007)

Büch TR, Heling D, Damm E, Gudermann T \& Breit A 2009 Pertussis toxinsensitive signaling of melanocortin-4 receptors in hypothalamic GT1-7 cells defines agouti-related protein as a biased agonist. Journal of Biological Chemistry 284 26411-26420. (doi:10.1074/jbc.M109.039339)

Butler AA, Kesterson RA, Khong K, Cullen MJ, Pelleymounter MA, Dekoning J, Baetscher M \& Cone RD 2000 A unique metabolic syndrome causes obesity in the melanocortin-3 receptor-deficient mouse. Endocrinology 141 3518-3521. (doi:10.1210/endo.141.9.7791)

Chai B, Li JY, Zhang W, Ammori JB \& Mulholland MW 2007 Melanocortin-3 receptor activates MAP kinase via PI3 kinase. Regulatory Peptides 139 115-121. (doi:10.1016/j.regpep.2006.11.003)

Chen AS, Marsh DJ, Trumbauer ME, Frazier EG, Guan XM, Yu H, Rosenblum CI, Vongs A, Feng Y, Cao L et al. 2000 Inactivation of the mouse melanocortin-3 receptor results in increased fat mass and reduced lean body mass. Nature Genetics 26 97-102. (doi:10.1038/79254)

Chien EY, Liu W, Zhao Q, Katritch V, Han GW, Hanson MA, Shi L, Newman AH, Javitch JA, Cherezov V et al. 2010 Structure of the human dopamine D3 receptor in complex with a D2/D3 selective antagonist. Science 330 1091-1095. (doi:10.1126/science.1197410)

Chu DT \& Klymkowsky MW 1989 The appearance of acetylated $\alpha$-tubulin during early development and cellular differentiation in Xenopus. Developmental Biology 136 104-117. (doi:10.1016/ 0012-1606(89)90134-6)

Cooke GS, Campbell SJ, Bennett S, Lienhardt C, McAdam KP, Sirugo G, Sow O, Gustafson P, Mwangulu F, van Helden P et al. 2008 Mapping of a novel susceptibility locus suggests a role for MC3R and CTSZ in human tuberculosis. American Journal of Respiratory and Critical Care Medicine 178 203-207. (doi:10.1164/rccm.200710-1554OC)

Cowley MA, Smart JL, Rubinstein M, Cerdan MG, Diano S, Horvath TL, Cone RD \& Low MJ 2001 Leptin activates anorexigenic POMC neurons through a neural network in the arcuate nucleus. Nature $\mathbf{4 1 1} 480-484$. (doi:10.1038/35078085)

Daniels D, Patten CS, Roth JD, Yee DK \& Fluharty SJ 2003 Melanocortin receptor signaling through mitogen-activated protein kinase in vitro and in rat hypothalamus. Brain Research 986 1-11. (doi:10.1016/S00068993(03)03162-7)

Erlenbach I, Kostenis E, Schmidt C, Serradeil-Le Gal C, Raufaste D, Dumont ME, Pausch MH \& Wess J 2001 Single amino acid substitutions and deletions that alter the $G$ protein coupling properties of the V2 vasopressin receptor identified in yeast by receptor random mutagenesis. Journal of Biological Chemistry 276 29382-29392. (doi:10.1074/jbc. M103203200)

Flanagan CA 2005 A GPCR that is not "DRY". Molecular Pharmacology 68 1-3. (doi:10.1124/mol.105.014183)
Gantz I, Konda Y, Tashiro T, Shimoto Y, Miwa H, Munzert G, Watson SJ, DelValle J \& Yamada T 1993 Molecular cloning of a novel melanocortin receptor. Journal of Biological Chemistry 268 8246-8250.

Getting SJ, Allcock GH, Flower R \& Perretti M 2001 Natural and synthetic agonists of the melanocortin receptor type 3 possess anti-inflammatory properties. Journal of Leukocyte Biology 69 98-104.

Getting SJ, Lam CW, Chen AS, Grieco P \& Perretti M 2006 Melanocortin 3 receptors control crystal-induced inflammation. FASEB Journal 20 2234-2241. (doi:10.1096/fj.06-6339com)

Han M, Gurevich VV, Vishnivetskiy SA, Sigler PB \& Schubert C 2001 Crystal structure of $\beta$-arrestin at 1.9 A: possible mechanism of receptor binding and membrane translocation. Structure 9 869-880. (doi:10.1016/S09692126(01)00644-X)

Huang H \& Tao YX 2012 Pleiotropic functions of the transmembrane domain 6 of human melanocortin-4 receptor. Journal of Molecular Endocrinology 49 237-248. (doi:10.1530/JME-12-0161)

Huang H \& Tao YX 2014 A small molecule agonist THIQ as a novel pharmacoperone for intracellularly retained melanocortin-4 receptor mutants. International Journal of Biological Sciences 10 817-824. (doi:10.7150/ijbs.9625)

Jaakola VP, Griffith MT, Hanson MA, Cherezov V, Chien EY, Lane JR, Ijzerman AP \& Stevens RC 2008 The 2.6 angstrom crystal structure of a human $\mathrm{A}_{2 \mathrm{~A}}$ adenosine receptor bound to an antagonist. Science $\mathbf{3 2 2}$ 1211-1217. (doi:10.1126/science.1164772)

Lefkowitz RJ 2013 A brief history of G-protein coupled receptors (Nobel Lecture). Angewandte Chemie 52 6366-6378. (doi:10.1002/anie.201301924)

Lu ZL, Gallagher R, Sellar R, Coetsee M \& Millar RP 2005 Mutations remote from the human gonadotropin-releasing hormone (GnRH) receptorbinding sites specifically increase binding affinity for GnRH II but not GnRH I: evidence for ligand-selective, receptor-active conformations. Journal of Biological Chemistry 280 29796-29803. (doi:10.1074/jbc. M413520200)

Marion S, Oakley RH, Kim KM, Caron MG \& Barak LS 2006 A $\beta$-arrestin binding determinant common to the second intracellular loops of rhodopsin family $\mathrm{G}$ protein-coupled receptors. Journal of Biological Chemistry 281 2932-2938. (doi:10.1074/jbc.M508074200)

Miyaji M, Kortum RL, Surana R, Li W, Woolard KD, Simpson RM, Samelson LE \& Sommers CL 2009 Genetic evidence for the role of Erk activation in a lymphoproliferative disease of mice. PNAS $\mathbf{1 0 6}$ 14502-14507. (doi:10.1073/pnas.0903894106)

Mo XL \& Tao YX 2013 Activation of MAPK by inverse agonists in six naturally occurring constitutively active mutant human melanocortin-4 receptors. Biochimica et Biophysic Acta 1832 1939-1948. (doi:10.1016/j.bbadis.2013.06.006)

Mo XL, Yang R \& Tao YX 2012 Functions of transmembrane domain 3 of human melanocortin-4 receptor. Journal of Molecular Endocrinology 49 221-235. (doi:10.1530/JME-12-0162)

Ni XP, Pearce D, Butler AA, Cone RD \& Humphreys MH 2003 Genetic disruption of $\gamma$-melanocyte-stimulating hormone signaling leads to salt-sensitive hypertension in the mouse. Journal of Clinical Investigation 111 1251-1258. (doi:10.1172/JCI200316993)

Okada T, Ernst OP, Palczewski K \& Hofmann KP 2001 Activation of rhodopsin: new insights from structural and biochemical studies. Trends in Biochemical Sciences 26 318-324. (doi:10.1016/S09680004(01)01799-6)

Palczewski K, Kumasaka T, Hori T, Behnke CA, Motoshima H, Fox BA, Le Trong I, Teller DC, Okada T, Stenkamp RE et al. 2000 Crystal structure of rhodopsin: a G protein-coupled receptor. Science $\mathbf{2 8 9}$ 739-745. (doi:10.1126/science.289.5480.739)

Patten CS, Daniels D, Suzuki A, Fluharty SJ \& Yee DK 2007 Structural and signaling requirements of the human melanocortin 4 receptor for MAP kinase activation. Regulatory Peptides 142 111-122. (doi:10.1016/j. regpep.2007.02.005)

Rajagopal S, Rajagopal K \& Lefkowitz RJ 2010 Teaching old receptors new tricks: biasing seven-transmembrane receptors. Nature Reviews. Drug Discovery 9 373-386. (doi:10.1038/nrd3024) 
Rasmussen SG, Choi HJ, Fung JJ, Pardon E, Casarosa P, Chae PS, Devree BT, Rosenbaum DM, Thian FS, Kobilka TS et al. 2011 Structure of a nanobody-stabilized active state of the $\beta_{2}$ adrenoceptor. Nature $\mathbf{4 6 9}$ 175-180. (doi:10.1038/nature09648)

Reiter E, Ahn S, Shukla AK \& Lefkowitz RJ 2012 Molecular mechanism of $\beta$-arrestin-biased agonism at seven-transmembrane receptors. Annual Review of Pharmacology and Toxicology 52 179-197. (doi:10.1146/ annurev.pharmtox.010909.105800)

Renquist BJ, Murphy JG, Larson EA, Olsen D, Klein RF, Ellacott KL \& Cone RD 2012 Melanocortin-3 receptor regulates the normal fasting response. PNAS 109 E1489-E1498. (doi:10.1073/pnas.1201994109)

Roselli-Rehfuss L, Mountjoy KG, Robbins LS, Mortrud MT, Low MJ, Tatro JB, Entwistle ML, Simerly RB \& Cone RD 1993 Identification of a receptor for gamma melanotropin and other proopiomelanocortin peptides in the hypothalamus and limbic system. PNAS 90 8856-8860. (doi:10.1073/pnas.90.19.8856)

Rosenbaum DM, Cherezov V, Hanson MA, Rasmussen SG, Thian FS, Kobilka TS, Choi HJ, Yao XJ, Weis WI, Stevens RC et al. 2007 GPCR engineering yields high-resolution structural insights into $\beta 2$-adrenergic receptor function. Science 318 1266-1273. (doi:10.1126/ science.1150609)

Rosenbaum DM, Rasmussen SG \& Kobilka BK 2009 The structure and function of G-protein-coupled receptors. Nature 459 356-363. (doi:10.1038/nature08144)

Roskoski R Jr 2012 ERK1/2 MAP kinases: structure, function, and regulation. Pharmacological Research 66 105-143. (doi:10.1016/j.phrs. 2012.04.005)

Sanchez-Laorden BL, Herraiz C, Valencia JC, Hearing VJ, JimenezCervantes C \& Garcia-Borron JC 2009 Aberrant trafficking of human melanocortin 1 receptor variants associated with red hair and skin cancer: steady-state retention of mutant forms in the proximal Golgi. Journal of Cellular Physiology 220 640-654. (doi:10.1002/jcp.21804)

Scheerer P, Park JH, Hildebrand PW, Kim YJ, Krauss N, Choe HW, Hofmann KP \& Ernst OP 2008 Crystal structure of opsin in its G-protein-interacting conformation. Nature $\mathbf{4 5 5}$ 497-502. (doi:10.1038/nature07330)

Sutton GM, Perez-Tilve D, Nogueiras R, Fang J, Kim JK, Cone RD, Gimble JM, Tschop MH \& Butler AA 2008 The melanocortin-3 receptor is required for entrainment to meal intake. Journal of Neuroscience $\mathbf{2 8}$ 12946-12955. (doi:10.1523/JNEUROSCI.3615-08.2008)

Sutton GM, Begriche K, Kumar KG, Gimble JM, Perez-Tilve D, Nogueiras R, McMillan RP, Hulver MW, Tschop MH \& Butler AA 2010 Central nervous system melanocortin-3 receptors are required for synchronizing metabolism during entrainment to restricted feeding during the light cycle. FASEB Journal 24 862-872. (doi:10.1096/fj.09-142000)

Tao YX 2007 Functional characterization of novel melanocortin-3 receptor mutations identified from obese subjects. Biochimica et Biophysic Acta 1772 1167-1174. (doi:10.1016/j.bbadis.2007.09.002)

Tao YX 2008 Constitutive activation of G protein-coupled receptors and diseases: insights into mechanism of activation and therapeutics. Pharmacology \& Therapeutics 120 129-148. (doi:10.1016/j.pharmthera. 2008.07.005)
Tao YX 2010 Mutations in the melanocortin-3 receptor (MC3R) gene: impact on human obesity or adiposity. Current Opinion in Investigational Drugs 11 1092-1096.

Tao YX 2014 Constitutive activity in melanocortin-4 receptor: biased signaling of inverse agonists. Advances in Pharmacology 70 135-154. (doi:10.1016/B978-0-12-417197-8.00005-5)

Tao YX \& Huang H 2014 Ipsen 5i is a novel potent pharmacoperone for intracellularly retained melanocortin-4 receptor mutants. Frontiers in Endocrinology 5 131. (doi:10.3389/fendo.2014.00131)

Tao YX \& Segaloff DL 2003 Functional characterization of melanocortin-4 receptor mutations associated with childhood obesity. Endocrinology 144 4544-4551. (doi:10.1210/en.2003-0524)

Tao YX \& Segaloff DL 2004 Functional characterization of melanocortin-3 receptor variants identify a loss-of-function mutation involving an amino acid critical for $G$ protein-coupled receptor activation. Journal of Clinical Endocrinology and Metabolism 89 3936-3942. (doi:10.1210/jc. 2004-0367)

Tao YX, Mizrachi D \& Segaloff DL 2002 Chimeras of the rat and human FSH receptors (FSHRs) identify residues that permit or suppress transmembrane 6 mutation-induced constitutive activation of the FSHR via rearrangements of hydrophobic interactions between helices 6 and 7 . Molecular Endocrinology 16 1881-1892. (doi:10.1210/me.2001-0199)

Tao YX, Huang H, Wang ZQ, Yang F, Williams JN \& Nikiforovich GV 2010 Constitutive activity of neural melanocortin receptors. Methods in Enzymology 484 267-279. (doi:10.1016/S0076-6879(10)84014-5)

Violin JD \& Lefkowitz RJ 2007 -Arrestin-biased ligands at seventransmembrane receptors. Trends in Pharmacological Sciences $\mathbf{2 8}$ 416-422. (doi:10.1016/j.tips.2007.06.006)

Wacker JL, Feller DB, Tang XB, Defino MC, Namkung Y, Lyssand JS, Mhyre AJ, Tan X, Jensen JB \& Hague C 2008 Disease-causing mutation in GPR54 reveals the importance of the second intracellular loop for class A G-protein-coupled receptor function. Journal of Biological Chemistry 283 31068-31078. (doi:10.1074/jbc.M805251200)

Wacker D, Wang C, Katritch V, Han GW, Huang XP, Vardy E, McCorvy JD, Jiang Y, Chu M, Siu FY et al. 2013 Structural features for functional selectivity at serotonin receptors. Science 340 615-619. (doi:10.1126) science.1232808)

Wang ZQ \& Tao YX 2011 Functional studies on twenty novel naturally occurring melanocortin-4 receptor mutations. Biochimica et Biophysic Acta 1812 1190-1199. (doi:10.1016/j.bbadis.2011.06.008)

Wang SX, Fan ZC \& Tao YX 2008 Functions of acidic transmembrane residues in human melanocortin-3 receptor binding and activation. Biochemical Pharmacology 76 520-530. (doi:10.1016/j.bcp.2008.05.026)

Warne T, Edwards PC, Leslie AG \& Tate CG 2012 Crystal structures of a stabilized $\beta 1$-adrenoceptor bound to the biased agonists bucindolol and carvedilol. Structure 20 841-849. (doi:10.1016/j.str. 2012.03.014)

Wright FA, Strug LJ, Doshi VK, Commander CW, Blackman SM, Sun L, Berthiaume Y, Cutler D, Cojocaru A, Collaco JM et al. 2011 Genomewide association and linkage identify modifier loci of lung disease severity in cystic fibrosis at 11p13 and 20q13.2. Nature Genetics $\mathbf{4 3}$ 539-546. (doi:10.1038/ng.838)

Received in final form 12 September 2014

Accepted 15 September 2014

Accepted Preprint published online 16 September 2014 http://jme.endocrinology-journals.org DOI: 10.1530/JME-14-0184
() 2014 Society for Endocrinology Printed in Great Britain 